\title{
Improved Learning Outcomes of My Job as a Religious Community through Scientific Approach Aided by Power Points in Class II elementary schools
}

\author{
Fauziah Ratna Andriyani \\ SD 2 Jepang Pakis Kecamatan Jati Kabupaten Kudus \\ fratna246@gmail.com
}

\section{Article History}

accepted $14 / 11 / 2020$

approved $21 / 11 / 2020$

published 26/11/2020

\begin{abstract}
The background of this research is the low learning outcomes of grade II SD 2 Jepang Pakis on the subject of My Task as a Religious Person. The aim of this research is to describe the application of the powerpoint assisted scientific approach to improve the learning outcomes of the material My Task As a Religious in grade II SD 2 Jepang Pakis. This research is a Classroom Action Research which lasts for two cycles. The subjects of this reseach were second grade students of SD 2 Jepang Pakis, Jati District, Kudus Regency. Data collection techniques used are through observation, tests, and documentation. In the first cycle, $65 \%$ of students reached the KKM and the remaining 35\% had not reached the KKM with a mean score of 78. While in the second cycle there were $87 \%$ of students who reached the KKM and the remaining $13 \%$ had not reached the KKM with a mean score of 83 . Based on these results, it can be concluded that the use of a scientific approach combined with PowerPoint media can improve the learning outcomes of grade II SD 2 Jepang Pakis in the academic year 2020/2021 for my assignment as a religious community.
\end{abstract}

Keywords: learning outcomes, scientific, powerpoint

\begin{abstract}
Abstrak
Latar belakang penelitian ini adalah rendahnya hasil belajar peserta didik kelas II SD 2 Jepang Pakis pada materi Tugasku Sebagai Umat Beragama.Tujuan penelitian ini adalah untuk mendekripsikan penerapan pendekatan saintifik berbantuan powerpoint untuk meningkatkan hasil belajar materi Tugasku Sebagai Umat Beragama pada peserta didik kelas II SD 2 Jepang Pakis. Penelitian ini merupakan Penelitian Tindakan Kelas yang berlangsung selama dua siklus. Subyek penelitian ini adalah peserta didik kelas II SD 2 Jepang Pakis Kecamatan Jati Kabupaten Kudus. Teknik pengumpulan data yang dilakukan ialah melalui observasi, tes, dan dokumentasi. Pada siklus I ada 65\%peserta didik dapat mencapai KKM dan sisanya $35 \%$ belum mencapai KKM dengan nilai rerata 78 . Sedangkan pada siklus II ada $87 \%$ peserta didik yang mencapai KKM dan sisanya $13 \%$ belum mencapai KKM dengan nilai rerata 83 . Berdasarkan hasil tersebut, dapat disimpulkan bahwa penggunaan pendekatan saintifik yang dipadukan dengan media powerpoint dapat meningkatkan hasil belajar peserta didik kelas II SD 2 Jepang pakis tahun pelajaran 2020/2021 materi tugasku sebagai umat beragama.
\end{abstract}

Kata kunci: hasil belajar, powerpoint, saintifik

Social, Humanities, and Education Studies (SHEs): Conference Series https://jurnal.uns.ac.id/shes

p-ISSN 2620-9284

e-ISSN 2620-9292 


\section{PENDAHULUAN}

Menurut Sardjiyo (2011: 1.20) Pendidikan nasional yang berdasarkan Pancasila dan Undang-undang dasar Negara Republik Indonesia Tahun 1945 berfungsi mengembangkan kemampuan dan membentuk watak serta peradaban bangsa yang bermartabat dalam rangka mencerdaskan kehidupan bangsa, bertujuan untuk mengembangkan potensi peserta didik agar menjadi manusia yang beriman dan bertakwa kepada Tuhan Yang Maha Esa, berakhlak mulia, sehat, berilmu, cakap, kreatif, mandiri, dan menjadi warga Negara yang demokratis serta bertanggung jawab.

Sekolah sebagai tempat proses belajar mempunyai kedudukan yang sangat penting dalam dunia pendidikan. Oleh karena itu pendidikan di sekolah memegang peranan penting dalam rangka mewujudkan tercapainya pendidikan nasional secara optimal seperti yang diharapkan. Dalam proses belajar mengajar tersebut guru menjadi pemeran utama dalam menciptakan situasi interaktif yang edukatif, yakni interaksi antara guru dengan peserta didik, peserta didik dengan peserta didik dan sumber pembelajaran dalam menunjang tercapainya tujuan belajar.

Diimplementasikannya kurikulum 2013, sebagai pengganti kurikulum 2006 atau yang lebih dikenal dengan Kurikulum Tingkat Satuan Pendidikan (KTSP) mau tidak mau membawa sejumlah perubahan dalam sistem Pendidikan di Indonesia. Salah satunya terkait mata pelajaran. Salah satu perubahan yang paling menonjol dan bisa ditemukan pada jenjang Sekolah Dasar (SD) misalnya, adalah diterapkannya sistem pembelajaran berbasis tematik integratif. Pembelajaran tematik integratif (terpadu) sendiri merupakan pembelajaran yang memadukan berbagai mata pelajaran yang memiliki tema sama. Sistem ini diterapkan di SD karena karakteristik siswa yang masih memandang sesuatu secara holistik (menyeluruh). Bukan saja dianggap belum mampu memilih konsep dari berbagai disiplin ilmu, siswa SD juga dikenal dengan cara berpikirnya yang deduktif (dari yang umum ke bagian-bagian kecil). Oleh karena itu, pembelajaran tematik integratif diyakini dapat menjadi pembelajaran yang sesuai dengan karakteristik mereka.

Dalam hal pendekatan yang digunakan, pendekatan saintifik merupakan kerangka ilmiah pembelajaran yang diterapkan pada Kurikulum 2013. Pendekatan saintifik mengadaptasi langkah-langkah ilmiah pada sains. Proses pembelajaran dapat dipadankan dengan suatu proses ilmiah, karenanya Kurikulum 2013 mengamanatkan esensi pendekatan saintifik dalam pembelajaran. Pendekatan saintifik diyakini sebagai titian emas perkembangan dan pengembangan sikap, keterampilan, dan pengetahuan peserta didik.

Untuk mengembangkan sikap, ketrampilan, dan pengetahuan peserta didik, dalam proses pembelajaran yang bermakna, guru harus menggunakan media pembelajaran yang bervariasi. Salah satu media pembelajaran yang dapat digunakan guru adalah media power point. Dalam power point terdapat animasi yang tidak hanya berlaku pada teks tapi juga gambar, video, film, garis, dan sebagainya.

Dalam hal pelaksanaan proses pembelajaran di kelas II SD 2 Jepang Pakis masih menggunakan metode ceramah sehingga cenderung teacher centered, belum menggunakan media pembelajaran yang bervariasi dan peserta didik cenderung pasif. Hal tersebut mengakibatkan hasil belajar peserta didik rendah. Berdasarkan hasil pretest yang dilakukan oleh peneliti materi Tugasku Sebagai Umat Beragama, banyak peserta didik yang belum mencapai KKM. Dari 23 peserta didik hanya 9 peserta didik yang mencapai KKM dan terdapat 14 peserta didik yang belum mencapai KKM. SD 2 Jepang pakis memiliki KKM (Kriteria Ketuntasan Minimal) untuk semua mata pelajaran 75 dari skala 100 . Hal ini berarti ada $61 \%$ peserta didik yang belum mencapai KKM pada materi Tugasku sebagai umat beragama. Berdasarkan latar belakang maka peneliti bermaksud mengadakan penelitian dengan judul," PENINGKATAN HASIL BELAJAR TUGASKU SEBAGAI UMAT BERAGAMA MELALUI PENDEKATAN 
SAINTIFIK BERBANTUAN MEDIA POWER POINT PADA PESERTA DIDIK KELAS II SD 2 JEPANG PAKIS TAHUN PELAJARAN 2020/2021."

\section{METODE}

Penelitian ini disebut dengan Penelitian Tindakan Kelas (PTK) atau dalam istilah bahasa Inggris Classroom Action Research (CAR). PTK ialah suatu pendekatan untuk meningkatkan pendidikan dengan melakukan perubahan ke arah perbaikan terhadap hasil pendidikan dan pembelajaran. Arikunto (2010: 137) Penelitian PTK merupakan suatu pencermatan terhadap kegiatan yang segaja dimunculkan dan terjadi dalam sebuah kelas. Penelitian yang bertujuan untuk mengatasi permasalahan yang dihadapi guru sehingga dapat meningkatkan hasil belajar.Sedangkan data kuantitatif diperoleh dari hasil pemberian soal-soal tes di setiap siklus.

Subyek penelitian ini adalah seluruh peserta didik kelas II SD 2 Jepang Pakis, yang berjumlah 23 peserta didik. Sedangkan objek penelitian ini adalah keseluruhan proses dan hasil pembelajaran materi tugasku sebagai umat beragama di kelas II SD 2 Jepang Pakis. Tempat penelitian ini akan dilaksanakan di SD 2 Jepang Pakis, yang bertempatan di Jl. Kyai Mojo No 55 Kecamatan Jati Kabupaten Kudus Provinsi Jawa Tengah. Penelitian ini berlangsung 27 Oktober 2020 sampai dengan 28 November 2020. Instrumen yang digunakan dalam penelitian PTK ini adalah metode observasi, tes, dan dokumentasi. Teknik analisis data menggunakan teknik analisis kualitatif dan kuantitatif.

\section{HASIL DAN PEMBAHASAN}

Penelitian "Peningkatan Hasil Belajar Tugasku Sebagai Umat Beragama Melalui Pendekatan Saintifik Berbantuan Media PowerPoint Pada Peserta Didik Kelas II SD 2 Jepang Pakis Tahun Pelajaran 2020/2021" ini terlaksana melalui dua siklus. Dalam penelitian ini, peneliti menggunakan pendekatan saintifik berbantuan media PowerPoint. Pendekatan saintifik (scientific approach) adalah model pembelajaran yang menggunakan kaidah-kaidah keilmuan yang memuat serangkaian aktivitas pengumpulan data melalui observasi, menanya, eksperimen, mengolah informasi atau data, kemudian mengkomunikasikan (Kemendikbud, 2014). Menurut Rusman (2015), pendekatan saintifik merupakan pendekatan pembelajaran yang memberikan kesempatan pada siswa secara luas untuk melakukan eksplorasi dan elaborasi materi yang dipelajari, di samping itu memberikan kesempatan pada peserta didik untuk mengaktualisasikan kemampuan melalui kegiatan pembelajaran yang dirancang oleh guru. Menurut Hosnan (2014) pendekatan saintifik memiliki karakteristik sebagai berikut: 1) Berpusat pada siswa; 2) Melibatkan keterampilan proses sains dalam mengonstruksi konsep, hukum atau prinsip; 3) Melibatkan proses-proses kognitif yang potensial dalam merangsang perkembangan intelektual, khususnya keterampilan berpikir tingkat tinggi siswa, dan; 4) Dapat mengembangkan karakter siswa.

Pendekatan saintifik merupakan kerangka ilmiah pembelajaran yang diterapkan pada Kurikulum 2013. Selain itu, pendekatan saintifik juga diyakini sebagai titian emas perkembangan dan pengembangan sikap, keterampilan, dan pengetahuan peserta didik.Langkah-langkah pendekatan saintifik dalam proses pembelajaran meliputi mengamati (observing), menanya (questioning), mencoba (experimenting), mengolah data atau informasi dilanjutkan dengan menganalisis, menalar (associating), dan menyimpulkan, menyajikan data atau informasi (mengomunikasikan). Sedangkan, Microsoft Powerpoint adalah sebuah program aplikasi microsoft office yang berguna sebagai media presentasi dengan menggunakan beberapa slide.(http://blog.unnes.ac.id/ayukwitantri/2016/02/12/pengertian-sejarah-dan-fungsimicrosoft-powerpoint-beserta-kelebihannya/). Kegunaan atau fungsi dari Microsoft powerpoint adalah sebagai berikut : 1)Sarana untuk mempermudah sebuah presentasi. 
2)Membuat sebuah presentasi berbentuk softcopy sehingga dapat diakses oleh berbagai perangkat komputer. 3)Membuat presentasi dalam bentuk slide yang menarik dan cantik dengan dukungan fitur audio, video, gambar dan animasi serta template/desain yang akan dipergunakan. 4)Mempermudah dalam membuat, mengatur dan mencetak berbagai slide.

Pada siklus I, peneliti menyajikan tampilan powerpoint dengan banyak gambar, sedangkan pada siklus II peneliti menyajikan tampilan powerpoint dengan perpaduan gambar dengan video.

Setiap kompetensi dasar akan dapat diketahui ketercapaiannya berdasarkan KKM yang ditetapkan. KKM kelas II SD 2 Jepang Pakis adalah 75. KKM tersebut berfungsi sebagai acuan guru dalam menilai hasil belajar peserta didik yang sesuai Kompetensi Dasar. Berikut ini adalah hasil penelitian:

\section{Siklus I}

Berikut ini Tabel 1 (siklus I) mengenai ketuntasan hasil belajar peserta didik melalui tes tertulis menggunakan media pembelajaran power point yang berisi gambargambar pada pembelajaran Tugasku Sebagai Umat Beragama Melalui Pendekatan Saintifik Berbantuan Media Power Point Pada Peserta Didik Kelas II SD 2 Jepang Pakis Tahun Pelajaran 2020/2021dengan hasil penelitian yang dilakukan pada tanggal 2 November 2020 di SD 2 Jepang Pakis.

Tabel 1 Ketuntasan Hasil Belajar Peserta Didik

\begin{tabular}{clccc}
\hline No & \multicolumn{1}{c}{ Keterangan } & Jumlah & Presentasi & Kategori \\
\hline 1 & Diatas KKM & 15 & $65 \%$ & Tuntas \\
\hline 2 & Mencapai KKM & 0 & $0 \%$ & - \\
\hline 3 & Dibawah KKM & 8 & $35 \%$ & Belum Tuntas \\
\hline & Jumlah & $\mathbf{2 3}$ & $\mathbf{1 0 0 \%}$ & \\
\hline
\end{tabular}

Dari jumlah 23 peserta didik kelas II sebanyak 15 peserta didik (65\%) mendapatkan nilai diatas KKM, sedangkan sisanya sebanyak 8 peserta didik (35\%) mendapatkan nilai di bawah KKM.

\section{Siklus II}

Berdasarkan Tabel 2 (siklus II) yang dilaksanakan pada tanggal 9 November 2020 hasil belajar peserta didik di kelas II SD 2 Jepang Pakis dengan menggunakan media pembelajaran benda konkret terlihat adanya peningkatan dari siklus I atau siklus sebelumnya.

Tabel 2 Ketuntasan Hasil Belajar Peserta Didik (Pada Siklus II)

\begin{tabular}{clccc}
\hline No & Keterangan & Jumlah & Presentasi & Kategori \\
\hline 1 & Diatas KKM & 17 & $74 \%$ & Tuntas \\
\hline 2 & Mencapai KKM & 3 & $13 \%$ & Tuntas \\
\hline 3 & Dibawah KKM & 3 & $13 \%$ & Belum Tuntas \\
\hline & Jumlah & $\mathbf{2 3}$ & $\mathbf{1 0 0 \%}$ & \\
\hline
\end{tabular}

Dari jumlah peserta didik 23 di kelas II sebanyak 17 peserta didik (74\%) mendapatkan nilai diatas KKM dan 3 peserta didik (13\%) mendapatkan nilai setara dengan KKM, sedangkan sisanya sebanyak 3 peserta didik (13\%) mendapatkan nilai di bawah KKM.

Dari penelitian yang telah dilakukan dengan menggunakan II siklus, Hal ini dapat dilihat dari gambar diagram, yang mana setiap siklusnya memiliki peningkatan positif. 


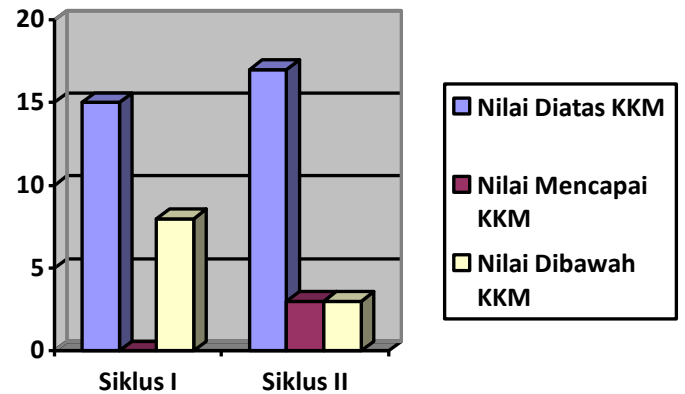

\section{Gambar 1 Diagram Ketuntasan Hasil Belajar Peserta Didik}

Penelitian ini menghasilkan $87 \%$ atau 20 peserta didik dari 23 peserta didik dinyatakan berhasil atau mampu melewati kompetensi dasar pada materi Tugasku Sebagai Umat Beragama.

Dari hasil Penelitian yang telah dilaksanakan dari gambar diagram peningkatan hasil belajar dapat dilihat perubahan peningkatan dari setiap siklus.

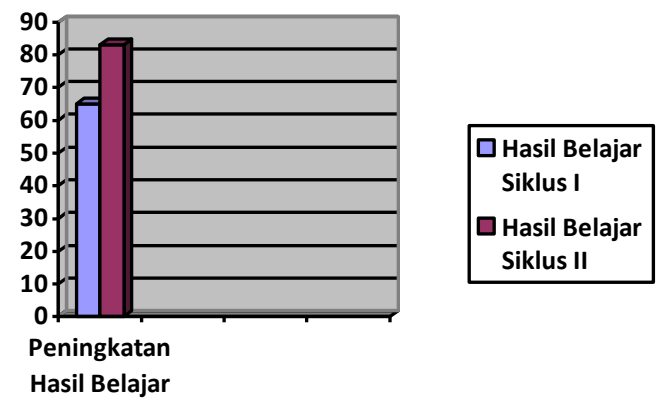

\section{Gambar 2 Diagram Peningkatan Hasil Belajar}

Pada siklus I ada 65\%peserta didik dapat mencapai KKM dan sisanya 35\% belum mencapai KKM dengan nilai rerata 78 . Sedangkan pada siklus II ada $87 \%$ peserta didik yang mencapai KKM dan sisanya $13 \%$ belum mencapai KKM dengan nilai rerata 83.

\section{SIMPULAN}

Berdasarkan hasil penelitian dan pembahasan diatas, dapat disimpulkan bahwa penggunaan pendekatan saintifik yang dipadukan dengan media powerpoint dapat meningkatkan hasil belajar peserta didik kelas II SD 2 Jepang pakis tahun pelajaran 2020/2021 pada materi tugasku sebagai umat beragama.

Dengan menggunakan media powerpoint, peserta didik menjadi sangat antusias dan aktif dalam mempelajari materi tugasku sebagai umat beragama sehingga terjadi peningkatan hasil belajar yang signifikan. Hal ini dapat dibuktikan seperti pada hasil penelitian yang telah berlangsung selama II siklus dan mendapatkan hasil ketuntasan $87 \%$ atau 20 peserta didik dari 23 peserta didik dinyatakan tuntas.

Untuk penelitian selanjutnya sebaiknya pada isi powerpoint disesuaikan dengan gaya belajar peserta didik kita. Sedangkan untuk platform pembelajaran daring yang digunakan bisa bervariasi disesuaikan dengan kemampuan guru dan wali murid serta kondisi daerah masing-masing. 


\section{DAFTAR PUSTAKA}

Aqib, Zaenal. (2011). Penelitian Tindakan Kelas untuk Guru SD, SDLB, TK. Bandung: Yramu Widya.

Arikunto, Suharsimi ,dkk. (2009). Penelitian Tindakan Kelas. Jakarta: PT Bumi Aksara. Hopkins, David. (1993). A Teachers's Guide to Classroom Research. Philadelphia:Open University Press

Hosnan, M. (2014). Pendekatan Saintifik dan Kontekstual dalam pembelajaran Abad 21. Bogor: Ghalia Indonesia

Komalasari, Kokom. (2011). Pembelajaran Kontekstual (Konsep dan Aplikasi). Bandung: Revika Aditama.

Majid, Abdul. (2014). Pembelajaran Tematik Terpadu. Bandung : Remaja Rosdakarya

Mulyatiningsih, Endang. (2011). Metode Penelitian Terapan Bidang pendidikan. Bandung: Alfabeta

Padmono, Y.(2010). Kekurangan dan kelebihan. Manfaat Penerapan PTK. Online: edukasikompasiana.com

Purwanto. (2009). Evaluasi Hasil Belajar. Jogjakarta: Pustaka Pelajar

Rusman. (2015). Pembelajaran Tematik Terpadu. Jakarta: raja Grafindo Persada

Rusyan, Tabrani. (1989). Pendekatan dalam Proses Belajar Mengajar. Bandung: CV Remadja Karya

Sardjiyo. (2011). Materi Pokok Pendidikan IPS di SD. Jakarta : Universitas Terbuka

Supriyono, Agus. (2012). Cooperative Learning .Teori dan Aplikasi PAIKEM. Jogjakarta: Pustaka pelajar.

Trianto. (2009). Mendesain Model Pembelajaran Inovatif-progresif. Jakarta: Kencana.

W., Sri Anitah dkk. (2009). Strategi Pembelajaran di SD. Jakarta: Universitas Terbuka. 